\title{
CANCER, FERTILITY, AND PSYCHOLOGICAL DISTRESS
} UDC 613.86-055.2:[ 616-006.04:618.2/.3

\author{
Vesna Kesić \\ University of Belgrade, Faculty of Medicine, Belgrade, Serbia
}

\begin{abstract}
The number of young women treated for cancer who want to give birth is increasing, due to postponing pregnancy for older age. On the other hand, the disease is more often diagnosed in the early stage, when conservative treatment is much more successful, even in gynecological cancer. Most young women diagnosed with cancer can expect to live for decades after treatment, which makes many life issues, such as future fertility, increasingly important. This has led to the separation of Oncofertility as a new field in oncology, which includes all procedures for the treatment of malignant disease with the aim of preserving fertility, but without compromising the oncological outcome. And while the problem of fertility may not be a priority at the time of diagnosis, over time it becomes more important. Infertility resulting from cancer treatment has a major impact on quality of life. The turmoil experienced by women who are simultaneously faced with cancer and possible loss of fertility leave emotional consequences, especially if the localization of the disease directly affects the reproductive organs. Coping not just with medical issues, but with two psychological traumas at the same time increases susceptibility to distress. Helping to preserve the quality of life and the psychological aspect of caring for patients with malignant diseases who want to preserve the possibility of childbirth should become an indispensable part of treatment. Recognizing and managing negative emotions in cancer patients is a priority that aims to improve their quality of life.
\end{abstract}

Key words: cancer, fertility, oncofertility, psychological distress.

\section{INTRODUCTION}

The number of young women who have been treated for cancer and want to give birth is increasing, due to delayed childbearing. On the other hand, cancer is more often diagnosed in the early stages, when treatment with conservative methods is increasingly successful, even in gynecological cancer. Fertility sparing surgical methods in gynecological oncology improve not only quality of life in the psycho-social and sexual sense, but also

Received November 3, 2020 / January June 28, 2021

Corresponding author: Vesna Kesić

University of Belgrade, Faculty of Medicine, Dr Subotića 8, 11000 Belgrade, Serbia

E-mail: vek1@mts.rs 
preserve reproduction. Informing women and family members about various aspects of the disease, both medical and psychological, can significantly contribute to the prevention, or alleviation of, psychological problems in the patient and her family.

The mentioned circumstances have led to the separation of Oncofertility as a new field in oncology, which includes all procedures for preserving fertility during the treatment of malignant disease, without compromising the oncological outcome. Oncofertility is not well known in the field of social sciences. In order to improve the quality of life of women who are struggling to preserve fertility during or after cancer treatment, in addition to oncologists and reproductive medicine specialists, it is necessary to educate professionals who provide psychological help and social support regarding oncofertility problems.

Every year, over 150,000 women aged 20-45 are diagnosed with cancer in Europe (Bray et al. 2020). Thanks to advances in therapy over the past 25 years, the outcome of these patients has improved significantly, with an overall 5-year survival rate of over $80 \%$. In young cancer patients (Adolescents and Young Adults-AYA, ages 15 to 39), the 5-year survival rate in the United States is $84.5 \%$ (Howlader et al. 2019). Similar data come from England where mortality in this age group was found to have a declining trend, decreasing from $8.3 \%$ to $5 \%$ (Anderson and Nichols, 2020). Most young women diagnosed with cancer can expect to live for decades after treatment, which makes many life issues, such as future fertility, increasingly important. Women under the age of 50, treated for cancer, experience greater psychological distress than the elderly, and the issue of fertility is among the problems that bother them the most (Duffy and Allan 2009).

Clinicians, researchers, and societies of cancer survivors are beginning to recognize infertility as a late effect of cancer treatment, which negatively affects the quality of life of young cancer patients, as well as the importance that building a family has for these women. Recognizing this concern, the American Society of Clinical Oncology (ASCO) has published recommendations on preserving fertility in patients being treated for cancer (Lee et al. 2006). These guidelines instruct oncologists to discuss the risk of infertility after treatment for malignancy with their patients. They should be prepared to discuss various fertility options or to refer the patient to a reproductive medicine specialist.

Despite the fact that ASCO published these recommendations back in 2006 and has supplemented them two times since (Oktay et al. 2018), research among America's most eminent oncologists has shown that less than $50 \%$ of them refer patients to reproductive medicine specialists (Quinn et al., 2009). Research in academic medical centers has yielded similar results, with less than $40 \%$ of patients being referred to reproductive medicine specialists, although $95 \%$ of the surveyed physicians said they routinely discuss the effects of cancer treatment on fertility with their patients (Forman et al. 2010). In a similar study conducted in France, only $46 \%$ of all surveyed doctors said they discussed infertility risks in patients of a reproductive age, and even fewer (22\%) referred them to a fertility center before starting treatment (Sallem et al., 2018). Only 14\% of doctors considered themselves versed in fertility preservation techniques, and ovarian transposition was the most frequently mentioned technique during consultations. Doctors believe that they lack the knowledge and tools that would enable them to provide patients with appropriate information. A review of in-hospital clinical trials for childhood cancer, gynecological cancer, and stem cell transplantation, which found that only $47 \%$ of informed treatment consents contained information on the risk of infertility after cancer treatment (Nurden et al. 2009), is consistent with these findings. 
Although infertility is a frequent consequence of the treatment of a malignant disease, in the initial stages of treatment, the concern about infertility is usually secondary to the concern for survival. A woman diagnosed with cancer must process complex information about further treatment. The decision-making process for acceptance of proposed therapeutic modalities has long been recognized as lengthy and particularly difficult for women (Duffy and Allan, 2009). For some women, infertility can be unexpected because they have not been able to process or remember the information about the side effects of the treatment that the oncologist showed them during their conversation about treatment.

Given that doctors often do not discuss future fertility with their patients, the failure to initiate this conversation can be experienced by women as a clear impossibility to preserve their ability to give birth. They are often forced to make treatment choices for their survival, which has a negative impact on fertility and their desire to give birth. It has been found that women who lose fertility after treatment due to gynecological malignancies feel deprived of choice (Corney et al. 1992). At the same time, they may feel that they should be grateful, just having been able to survive cancer (Carter et al. 2007).

While the problem of fertility may not come first at the time of diagnosis, over time it becomes more important. About $75 \%$ of reproductive-aged women diagnosed with cancer defer childbearing wishes (La Rosa 2019). Fertility-related psychological distress is prevalent and persistent in cancer patients and survivors (Logan et al. 2019). Women treated for cancer have higher scores of depression and distress if they are not provided with sufficient information about future reproductive capabilities (Carter et al. 2005).

A study of more than 600 women with breast cancer found that $73 \%$ of patients had some degree of concern about the possibility of becoming infertile after treatment, and $29 \%$ said their desire to preserve fertility would influence their decision on cancer treatment. In fact, many women have suggested that they could choose less toxic doses of chemotherapy to preserve fertility, even if it could increase the risk of recurrence of the malignancy (Partridge et al. 2004).

Concerns about future reproductive abilities that accompany cancer treatment may be or are usually negatively related to quality of life (Logan et al. 2019). The diagnosis of cancer itself represents a difficult emotional impact on women. Research has shown that infertility, as a unique health problem, has a level of suffering comparable to that of coping with a life-threatening disease such as cancer (Loscalzo and Clark 2007). Infertility itself is associated with significant psychological distress, with levels of depression twice as high as in women who do not have this problem, while quality of life is reduced in the areas of emotional well-being, interpersonal relationships and sexuality (Carter et al. 2010a).

It has been shown that the psychological impact of treatment-related infertility is not negligible: $77 \%$ of patients exhibit a clinically significant level of suffering (distress) in regard to fertility loss (Carter et al. 2010a).

In particular, it has been emphasized that psychological distress related to infertility is more pronounced in women who have not yet started their own families and would still like to do so. Furthermore, the literature on the topic reports a significant presence of anxiety, depression, low self-esteem, anger, irrational beliefs about cancer, suicidal thoughts and sleep disorders (Desphande et al. 2015; Chan et Wang 2017).

The turmoil experienced by women who are simultaneously diagnosed with cancer and potential infertility leaves emotional consequences, which are described as "Adding the insult to injury" or "Double trauma", especially if the localization of the disease is such that it directly affects the reproductive organs (Gamel et al. 2000). The synergistic 
effect of coping with two different traumas increases the susceptibility to psychological distress that can affect a woman's mental health. Thus, it could be said that the simultaneous experience of cancer and infertility could be a risk factor for prolonged reactions of sadness and potentially inadequate coping with the problem. The patient must face both the potential and the actual threat of infertility, which jeopardizes her desire to start or expand a family in the period after treatment (Kesic 2015).

Concerns about future reproductive abilities that accompany cancer treatment may be or are usually negatively related to quality of life (Logan et al. 2019). Parenting has been cited as an important aspect of life for cancer patients. An increasing group of cancer patients who have taken extensive measures to preserve their fertility have emotional difficulties. One of the older studies showed that women with infertility have constant feelings of sadness and regret, as a consequence of the cancer treatment, which lasted for more than a year after treatment (Carter et al. 2010b). The results of recent studies of the quality of life of patients with initial cervical cancer treated with methods that preserve fertility show that indicators of functional and physical well-being which have been significantly deteriorating for a period of 6 months, return to normal after that time, but that the emotional state remains worse 6 months, one year, but also two and four years after the end of treatment (Fleming et al. 2016)

Psychological experience, however, differs in some women, depending on the cause, the degree of fertility impairment, the importance attached to the desire to have a biological child, as well as the availability of reproductive medicine or the desire to adopt a child. Although there are several modern techniques for preserving fertility today, as well as the possibility of adopting a child, a woman's feeling that she cannot have her own child can be very traumatic. The potential loss of fertility could be more distressing than the cancer itself (La Rosa et al. 2020).

The possibilities for preserving fertility exist, but they are very complex. The complexity of these procedures requires that a woman weigh the strength of her desire to preserve the potential of childbirth, as opposed to a possible delay in treatment and, with everything, the uncertain outcome of future fertility.

Infertility treatment can lead to a number of emotional problems, as well as exhaust women and couples both psycho-physically and financially. Unfortunately, a significant obstacle for many cancer patients is the cost of fertility procedures. A study examining the experiences and financial concerns of people treated for cancer who want to build a family using assisted reproductive technology (ART) identified four main groups of problems: emotional experiences, financial barriers to building a family after cancer, the impact on partnerships, and a disrupted life pathway. Negative emotions were ubiquitous, but balanced with hope and optimism that parenthood would be realized. However, the combination of high costs of ART or adoption costs, the financial impact of malignancy treatment, and limited sources of support, may cause financial stress with extreme consequences.

Health insurance does not usually cover these costs, as they are not considered compulsory health care. Further, faced with these high costs, many survivors reported concern and guilt (Benedict et al. 2018). There are suggestions that insurance should cover iatrogenic infertility resulting from cancer treatment, similar to other iatrogenic treatment consequences such as breast reconstruction after mastectomy or wigs for alopecia.

Despite concerns of cancer patients which include worry about costs and potential risks, the follow-up of survivors who tried to preserve fertility showed that $92.3 \%$ of them felt well because of the decision to choose a fertility preservation treatment (Friedman et al. 2011). However, the fact that patients with a recurrence of malignant disease may die and 
leave a minor child with one parent is an additional ethical issue. There is an opinion that it can be unethical to allow reproduction to a woman if she is expected to live shorter. However, the opinion of the Ethics Committee of the Association for Reproductive Medicine is that this reason does not have to be convincing, given that the risk of recurrence for many patients may not be particularly high, and that a child can have a meaningful life despite the death of a parent (Matthews et al. 2012). Also, legal restrictions may call into question the role of a person being treated for cancer as a parent. A recent study showed that adoption agencies may be reluctant to consider people treated for malignancy as potential parents. Possible health problems and the risk of relapse after treatment may be an obstacle in the adoption process (Rosen 2005).

Before starting treatment, women should be aware of the fact that the treatment of malignant disease in premenopausal women often reduces fertility or leads to permanent ovarian failure. For example, after adjuvant chemotherapy for breast cancer, only $10 \%$ to $20 \%$ of women under the age of 35 develop permanent amenorrhea. However, the risk of ovarian failure increases tenfold for women treated in their late thirties, leaving up to $90 \%$ of women over the age of 40 with permanent ovarian failure (Canada et al. 2012). Due to the possible risk of premature menopause, couples who want children, and in whom a woman is treated, should be encouraged to have children as soon as possible from the oncological side.

The patient and her partner should be made aware of the growing success of infertility treatment with the help of reproductive technologies. Today, the techniques for preserving fertility before starting cancer treatment are highly developed. Most women can delay cancer treatment for a few days until the ovarian tissue is surgically removed, or for up to two to three weeks so that the ovarian stimulation cycle can take place and the oocytes (eggs) can be collected. These oocytes can be preserved in the unfertilized state by cryopreservation or can be used to create an embryo which is then stored by cryopreservation. In addition, it is necessary to provide information on modern options for assisted fertilization, including reproduction with the help of a third party. Patient-independent reproduction includes oocyte donation and a surrogate mother. New reproductive technologies are becoming more widely available and successful and can give hope to those who have no other pregnancy options. This information should be part of the Informed Consent that the patient signs before starting treatment.

Children and adolescents with malignant disease and/or their parents (if the child is very young) should be informed about the long-term consequences of treating the malignant disease, even if they do not ask. Most patients and their families will not refuse treatment that can save a child's life, because of possible future infertility, but they should know as much as possible about the diagnosis and therapy in order to better understand the causes of its late effects. A study of a cohort of adults treated for cancer as children found that almost $60 \%$ felt uncertain about their fertility status (Nicholson et al. 1993), and $44 \%$ had moderate to high general concerns about reproduction (Young et al. 2019). However, only $19 \%$ of young patients received advice on preserving fertility. Most studies have shown that adolescents have a strong desire to participate in decisions about their own cancer treatment and many have concerns about future fertility although age barriers have often prevented these discussions (Quinn et al. 2011).

Women report insufficient information and express a desire for more information either before or during treatment. Unfortunately, even if women want to consider fertility preservation, many do not receive timely information. Most women feel that the information obtained about fertility and the consequences of treatment (i.e., menopause, sexuality, 
mood swings) is insufficient. A study conducted among young women treated for breast cancer found that $72 \%$ of them discussed fertility dilemmas with their doctor, but only $51 \%$ felt that their questions were adequately answered (Partridge et al. 2004).

In many cases, women who have an infertility problem as a consequence of treating a malignant disease experience social isolation at the same time as psychological, psychosocial, and sometimes psychiatric disorders, such as anxiety and depression. These are all significant problems whose recognition and treatment would be of great benefit. Ideally, these issues should be identified during treatment, in the hope that early intervention could prevent more serious long-term consequences.

Patient counseling regarding future fertility should include a discussion not only about the side effects of the treatment on fertility, but also about the course of the future pregnancy and the potential risks for the child. A review of the psychosocial outcome in women after treatment for malignancy revealed that women had long-standing fears about their ability to carry a normal pregnancy, but were also concerned that pregnancy would increase the risk of disease recurrence. If they remain pregnant, women are additionally struggling with worries about the health risks of pregnancy and the risk of possible genetic problems in children.

Women treated for malignant disease may fear that their own health is not good enough to successfully carry a pregnancy. This fear may have a basis, because pregnancy is a cardiorespiratory stress, which is why those who have had anthracycline therapy or radiation in the chest area may benefit from a heart evaluation or pre-pregnancy lung function test.

If pregnancy occurs, women can experience significant anxiety generating fear that they will have unhealthy offspring. Current findings suggest that there is no increased risk of genetic diseases in children whose parent has previously been treated for malignancy (Signorello et al. 2012; Rosenberg 2012). Because of all these problems, when patients previously treated for cancer are advised regarding a planned pregnancy, it must first be considered whether there is a risk that the tumor will be inherited. Family history is crucial, including a full family history of the spouse.

Finally, there is another very important issue that connects ethics and law. Persons whose gametes, embryo or gonadal tissue have been submitted for cryopreservation in order to preserve fertility, should leave clear instructions on how these tissues will be disposed of in the future. This is best done when gametes or tissue are taken. It is crucial that the patient (or legal representative) determines exactly what to do with the gametes or tissue if the patient dies (Robertson 2005). The written document must specify whether the frozen material should be discarded or can be used by certain persons for posthumous reproduction. Posthumous reproduction is a new field in which neither the medical nor legal relations have yet been resolved.

The main problem is that the deceased agreed to the posthumous use of his material. The legal system respects the patient's previous wishes not to use or destroy reproductive material. Similarly, if the deceased gave instructions to use the material, it should be done. Several court systems and legal regulations already recognize that a child born after a posthumous conception or implantation becomes the legal heir or qualifies for benefits provided by law. 


\section{CONCLUSION}

Doctors treating young patients diagnosed with malignancy should be aware of the negative effects of cancer treatment on fertility and ways to minimize these effects. If the toxic effects of treatment on the gonads cannot be avoided, the patients should have knowledge about the possibilities of preserving fertility. Although many doctors who treat cancer in young people are sensitive to these issues, oncologists have traditionally focused more on providing the most effective treatment, and less on the quality of life after treatment. Therefore, they must know to whom to refer patients who want to preserve fertility. On the other hand, specialists in reproductive medicine must be aware that the fact that someone has been diagnosed with cancer or that he has survived the acute or prolonged phase of dealing with cancer, distinguishes this patient from other patients with infertility. They must cooperate with the oncologist, because there are numerous differences in the type of tumor and the method of treatment, which requires that the treatment strategy be adjusted to each individual case. In addition, knowledge about oncofertility is necessary for mental health practitioners who take care of cancer patients. Only in this way will they be able to explore and define with their clients new ways of living filled with satisfaction and in accordance with a person's value systems, despite cancer treatment and fertility problems.

\section{REFERENCES}

Anderson C., H. B. Nichols. "Trends in Late Mortality Among Adolescent and Young Adult Cancer Survivors". JNCI J Natl Cancer Inst 112, 10 (2020): 994-1002. doi:10.1093/jnci/djaa014

Benedict, C., J-A. Mc Leggon, B. Thom, J. F. Kelvin, M. Landwehr, S. Watson and J. S. Ford. "Creating a family after battling cancer is exhausting and maddening": Exploring real-world experiences of young adult cancer survivors seeking financial assistance for family-building after treatment”. Psychooncology 27, 12 (2018): 2829-2839. doi:10.1002/pon.4898.

Bray, F., J. Ferlay, I. Soerjomataram, R. L. Siegel, L. A. Torre, A. Jemal. "Global cancer statistics 2018: GLOBOCAN estimates of incidence and mortality worldwide for 36 cancers in 185 countries [published correction appears in CA Cancer J Clin 2020 Jul; 70 (4) :313]. CA Cancer J Clin 68, 6 (2018): 394-424. doi:10.3322/caac. 21492

Canada, A. L., and L. R. Schover. "The Psychosocial Impact of Interrupted Childbearing in Longterm Female Cancer Survivors". Psychooncology 21, 2 (2012): 134-143. doi: 10.1002/pon.1875

Carter, J., K. Rowland, D. Chi, C. Brown, N. Abu-Rustum, M. Castielb, and R. Barakat. "Gynecologic cancer treatment and the impact of cancer-related infertility". Gynecol Oncology 97 (2005): 90-95. doi:10.1016/j. ygyno.2004.12.019

Carter, J., Y. Sonoda, and N. R. Abu-Rustum. "Reproductive concerns of women treated with radical trachelectomy for cervical cancer". Gynecol Oncol 105, 1 (2007): 13-16. doi:10.1016/j.ygyno.2006.10.059

Carter, J., D. S. Chi, C. L. Brown, N. Abu-Rustum, M. Castiel, and R. Barakat. "Cancer-related infertility in survivorship". International Journal of Gynecological Cancer 20, 1 (2010): 2-8. doi: 10.1016/j.ygyno.2004. 12.019.

Carter, J., L. Raviv, L. Applegarth, J. S. Ford, L. Josephs, E. Grill, C. Sklar, Y. Sonoda, R. E. Baser, and R. R. Barakat. "A cross-sectional study of the psychosexual impact of cancer-related infertility in women: thirdparty reproductive assistance". Journal of Cancer Survivorship 4, 3 (2010): 236-246. doi: 10.1007/s11764010-0121-2

Chan, J. L. and E. T. Wang. "Oncofertility for women with gynecologic malignancies”. Gynecol Oncol 144, 3 (2017): 631-636. https://doi. org/10.1016/j.ygyno.2016.12.013

Corney, R., H. Everett, A. Howells, A. Howells, M. Crowther. "The care of patients undergoing surgery for gynaecological cancer: The need for information, emotional support and counselling". J Adv Nurs 17 (1992): 667-671. doi.org/10.1111/j.1365-2648.1992.tb01962.x

Deshpande, N. A., I. M. Braun, and F. L. Meyer. "Impact of fertility preservation counseling and treatment on psychological outcomes among women with cancer: A systematic review". Cancer 121, 22 (2015): 39383947. https://doi.org/10.1002/cncr.29637 
Duffy, C., and S. Allan. "Medical and Psychosocial Aspects of Fertility After Cancer". Cancer J 15, 1 (2009): 27-33. doi: 10.1097/PPO.0b013e3181976602

Fleming, N. D., P. T. Ramirez, P. T. Soliman, K. M. Schmeler, G. B. Chisholm, A. M. Nick, S. N. Westin and M. Frumovitz. "Quality of Life after Radical Trachelectomy for Early Stage Cervical Cancer: A 5-year Prospective". Evaluation.Gynecol Oncol 143, 3 (2016): 596-603. DOI: 10.1016/j.ygyno.2016.10.012

Forman, E. J., C. K. Anders, and M. A. Behera. "A nationwide survey of oncologists regarding treatmentrelated infertility and fertility preservation in female cancer patients". Fertility and Sterility 94, 5 (2010): 1652-1656. doi.org/10.1016/j.fertnstert.2009.10.008

Friedman, B. E., K. O'Leary, and L. M. Westphal. "Follow-up survey of cancer survivors who underwent ovarian stimulation for fertility preservation". Fertility and Sterility 95, 4 (2011): supplement S12-S13. doi.org/10.1016/j.fertnstert.2011.01.068

Gamel, C., M. Hengeveld, and B. Davis. "Informational needs about the effects of gynaecological cancer on sexuality: A review of the literature". J Clin Nurs 9 (2000): 5678. doi.org/10.1046/j.1365-2702.2000.00416.x

Howlader, N., A. M. Noone, M. Krapcho, D. Miller, A. Brest, M. Yu, J. Ruhl, Z. Tatalovich, A. Mariotto, D. R. Lewis, H. S. Chen, E. J. Feuer, K. A. Cronin (eds). SEER Cancer Statistics Review, 1975-2017, National Cancer Institute. Bethesda, MD, 2020. https://seer.cancer.gov/csr/1975_2017/, based on November 2019 SEER data submission, posted to the SEER web site, April 2020.

Kesic V. "Psiho-socijalni i etički aspekti udruženosti kancera i trudnoće". U Kancer, fertilitet i trudnoća, uredila V. Kesić, 332-347. Beograd: Zavod za izdavanje udžbenike, 2015.

La Rosa, V. L., M. Shah, I. Kahramanoglu, T. M. Cerentini, M. Ciebiera, L-T. Lin, M. Dirnfeld, P. Minona and J. Tesarik. "Quality of life and fertility preservation counseling for women with gynecological cancer: An integrated psychological and clinical perspective". J Psychosom Obstet Gynaecol 1-7 (2019). https://doi.org/10.1080/ 0167482X.2019.164842

La Rosa, V., S. Garzon, G. Gullo, M. Fichera, G. Sisti, P. Gallo, G. Riemma, and A. Schiattarella. "Fertility preservation in women affected by gynaecological cancer: The importance of an integrated gynaecological and psychological approach". Ecancer 14 (2020):1035. https://doi.org/10.3332/ecancer.2020.1035

Lee, S. J., L. R. Schover, A. H. Partridge, P. Patrizio, W. H. Wallace, K. Hagerty, L. N. Beck, L. V. Brennan and K. Oktay. "American Society Clinical Oncology recommendations on fertility preservation in cancer patients". Journal of Clinical Oncology 24, 18 (2006): 2917-2931. doi: 10.1200/JCO.2006.06.5888.

Logan, S., J. Perz, J. M. Ussher, M. Peate, and A. Anazodo. "Systematic review of fertility-related psychological distress in cancer patients: Informing on an improved model of care". Psycho-Oncology 28 (2019): 22-30. https://doi.org/ 10.1002/pon.4927

Loscalzo, M. J., K. L. Clark. "The Psychosocial Context of Cancer-Related Infertility". In Oncofertility Fertility Preservation for Cancer Survivors edited by T. K. Woodruff, and K. A. Snyder. Cancer Treatment and Research 138 (2007): 180-190. Springer, Boston, MA. /doi.org/10.1007/978-0-38772293-1_13

Matthews, M. L., B. S. Hurst, P. B. Marshburn, R. S. Usadi, M. A. Papadakis, and T. Sarantou. "Cancer, Fertility Preservation, and Future Pregnancy: A Comprehensive Review". Obstetrics and Gynecology International Volume (2012): Article ID 953937. doi:10.1155/2012/953937

Nicholson, S. H. and J. Byrne. "Fertility and Pregnancy after Treatment for Cancer during Childhood and Adolescence". Cancer 71 (1993): 3392-3399. doi.org/10.1002/1097-0142(19930515)71:10+<3392::AIDCNCR2820711743>3.0.CO;2-F

Oktay, K., B. E. Harvey, A. H. Partridge, G. P. Quinn, J. Reinecke, H. S. Taylor, W. H. Wallace, E. T. Wang, A. W. Loren. "Fertility Preservation in Patients With Cancer: ASCO Clinical Practice Guideline Update". $J$ Clin Oncol 36 (2018): 1994-2001. doi: 10.1200/JCO.2018.78.1914

Partridge, A. H., S. Gelber, J. Peppercorn, E. Sampson, K. Knudsen, M. Laufer, R. Rosenberg, M. Przypysny, A. Rein, and E. P. Winer. "Web-based survey of fertility issues in young women with breast cancer". Journal of Clinical Oncology 22, 20 (2004): 4174-4183. doi: 10.1200/JCO.2004.01.159.

Raviv, L., L. Applegarth, J. S. Ford, L. Josephs, E. Grill, C. Sklar, Y. Sonoda, R. E. Baser, and R. R. Barakat. "A crosssectional study of the psychosexual impact of cancer-related infertility in women: Third-party reproductive assistance". Journal of Cancer Survivorship 4, 3 (2010): 236-246. doi: 10.1007/s11764-010-0121-2

Quinn, G. P., S. T. Vadaparampil, J-H. Lee, P. B. Jacobsen, G. Bepler, J. Lancaster, D. L. Keefe, and T. L. Albrecht. "Physician referral for fertility preservation in oncology patients: A national study of practice behaviors". Journal of Clinical Oncology 27, 35 (2009): 5952-5957. doi: 10.1200/JCO.2009.23.0250

Quinn, G. P., D. Murphy, C. Knapp, D. K. Stearsman, K. L. Bradley-Klug, K. Sawczyn and M. L. Clayman. "Who decides? Decision making and Fertility Preservation in Teens with Cancer: A Review of the literature". J Adolesc Health 49, 4 (2011): 337-346. doi:10.1016/j.jadohealth.2011.01.005

Robertson, J. A. "Cancer and Fertility: Ethical andLegal Chalenges". J Natl Canc Inst Monog 34 (2005): 104106. DOI: 10.1093/jncimonographs/lgi008 
Rosen, A. "Third-party reproduction and adoption in cancer patients". J Natl Cancer Inst Monogr 34 (2005): 91-93. doi: 10.1093/jncimonographs/lgi021

Rosenberg, K. "No Increased Risk of Genetic Damage in Children of Cancer Survivors". American Journal of Nursing 112, 3 (2012): 16. doi: 10.1097/01.NAJ.0000412623.65014.6c

Sallem, A., J. Shore, I. Ray-Coquard, L. Ferreux, M. Bourdon, M. Maignien, C. Patrat, J-P. Wolf, and K. PocateCheriet. "Fertility preservation in women with cancer: A national study about French oncologists awareness, experience, and feelings". Journal of Assisted Reproduction and Genetics 35, 10 (2018): 1843-1850.

Signorello, L., J. L. Mulvihill, D. M. Green, H. M. Munro, M. Stovall, R. E. Weathers, A. C. Mertens, J. A. Whitton, L. L. Robison, and J. D. Jr Boice. "Congenital Anomalies in the Children of Cancer Survivors: A Report from the Childhood Cancer Survivor Study”. J Clin Oncol 30 (2012): 239-245. DOI: 10.1200/JCO.2011.37.2938

Nurden, S. K., B. I. Karp, M. R. Viera, S. Liu, A. Idriss, and P. Stratton. "Conveying future fertility risk to patients participating in clinical trials using total body irradiation or cytotoxic agents". Fertility and Sterility 92 (2009) (supplement 3): S 184. doi.org/10.1016/j.fertnstert.2009.07.1383

Young, K., K. Shliakhtsitsava, L. Natarajan, E. Myers, A. C. Dietz, J. R. Gorman, M. E. Martinez, B. W. Whitcomb, and H. I. Su. "Fertility counseling before cancer treatment and subsequent reproductive concerns among female adolescent and young adult cancer survivors". Cancer 125, 6 (2019): 980-989. doi:10.1002/cncr.31862.

\section{KANCER, FERTILITET I PSIHOLOŠKI DISTRES}

Broj mladih žena koje su lečene od kancera, a žele da rode je sve veći, zbog odlaganja rađanja za starije životno doba. S druge strane, bolest se češce dijagnostikuje u ranim stadijumima, kada je lečenje konzervativnim metodama mnogo uspešnije, čak i kod ginekološkog kancera. Većina mladih žena sa dijagnozom raka može očekivati da će živeti decenijama po završetku lečenja, što mnoga životna pitanja, kao što je buduća plodnost (fertilitet) čini sve važnijim. To je dovelo do izdvajanja Onkofertiliteta kao nove oblasti u onkologiji koja obuhvata sve postupke lečenja maligne bolesti sa ciljem očuvanja fertiliteta, ali bez ugrožavanja onkološkog ishoda. I dok problem plodnosti možda nije na prvom mestu u vreme postavljanja dijagnoze, tokom vremena on postaje sve važniji. Infertilnost koja je posledica lečenja kancera ima veliki efekat na kvalitet života. Previranja koja doživljavaju žene koje se istovremeno suočavaju sa dijagnozom raka i mogućim gubitkom plodnosti ostavljaju emocionalne posledice naročito ako lokalizacija bolesti direktno utiče na reproduktivne organe. Nošenje sa dve psihološke traume u isto vreme povećava osetljivost za nastanak distresa. Pomoć u očuvanju kvaliteta života $i$ psihološki aspekt brige o pacijentkinjama sa malignim bolestima koje žele da očuvaju mogućost rađanja trebalo bi da postane neizostavni deo lečenja. Prepoznavanje i zbrinjavanje anksioznosti $i$ depresije kod pacijentkinja sa kancerom je prioritet koji ima za cilj poboljšanje kvaliteta njihovog života.

Ključne reči: kancer, fertilitet, onkofertilitet, psihološki distres. 